\title{
PONDOK PESANTREN MASA DEPAN (Studi Pola Manajemen PP. Nahdlatun Nasyiin Bungbaruh Kadur Pamekasan)
}

\author{
MOH. MAHFUD dan ARTAMIN HAIRIT \\ STAI Al-Khairat Pamekasan \\ afudbahri@gmail.com dan aminhidayat2013@gmail.com
}

\begin{abstract}
Islamic education institutions had been in Indonesia since the earlier Islamic period. The growth of Islamic institution in Indonesia had been caused of influence of Sultans and 'Wali Songo'. The one of the Islamic institution here is 'Pondok Pesantren'. In the earlier colonial period, Pondok Pesantren had a big influence in the developing of human resources in Indonesia especially in the field of education. Pondok Pesantren have been made many innovations in their characters of teaching and education. It always needs to answer many challenges in the global era, in which the social problems become more complex. The article discusses about management of Pondok Pesantren Nahdlatun Nasyiin. In the case study, we found that (1) management of curriculum in Pondok Pesantren Nahdlatun Nasyiin is a combination model between formally government curriculum and Pesantren curriculum; (2) Student, equipment and finance managements in the Pesantren have used the open and modern management which apply the management functions; (3) in the management of social relation, they have applied traditional model in which the communication between 'Madrasah' and students' parents or society is still dominated by the Madrasah Committee.
\end{abstract}

\begin{abstract}
Abstrak
Lembaga pendidikan Islam telah ada di Indonesia sejak masa awal Islam di Indonesia. Pertumbuhan lembaga pendidikan Islam di Indonesia disebabkan oleh pengaruh para sultan dan 'Wali Songo'. Salah satu lembaga Islam di sini adalah 'Pondok Pesantren'. Pada awal masa kolonial, Pondok Pesantren memiliki pengaruh besar dalam pengembangan sumber daya manusia di Indonesia khususnya di bidang pendidikan. Pondok Pesantren telah membuat banyak inovasi dalam karakter mereka dari pendidikan dan pengajaran. Ada berbagai tantangan di era global yang harus dijawab dan dihadapi, dimana masalah sosial menjadi lebih kompleks. Artikel ini membahas tentang pengelolaan Pondok Pesantren Nahdlatul Nasyiin. Dalam penelitian studi kasus ini, kami menemukan bahwa (1) manajemen kurikulum di Pondok Pesantren Nahdlatul Nasyiin adalah model kombinasi antara kurikulum resmi pemerintah dan kurikulum Pesantren; (2) Manajemen siswa, sarana dan prasarana dan keuangan di Pesantren menggunakan manajemen terbuka dan modern yang menerapkan fungsi manajemen; (3) dalam pengelolaan hubungan sosial, pondok pesantren menerapkan model tradisional di mana komunikasi antara 'Madrasah' dan orang tua siswa atau masyarakat masih didominasi oleh Komite Madrasah.
\end{abstract}

\section{Kata Kunci: Management Masa Depan, Pondok Pesantren}

\section{Pendahuluan}

Pondok Pesantren adalah lembaga pendidikan Islam tertua yang pada awal berdirinya berfungsi sebagai benteng pertahanan Islam. Selain itu, Pondok Pesantren 
juga berfungsi sebagai pusat dakwah dan pusat pengembangan masyarakat muslim di Indonesia. Sejarah juga telah membuktikan kontribusi pesantren dalam rangka turut mendirikan negara Republik Indonesia. Banyak ulama' dan santri yang gugur dalam memperjuangkan dan mempertahankan kemerdekaan. Ulama' bersama santri rela mengisolisir diri sambil memotivasi masyarakat untuk tidak bekerjasama dengan penjajah. Pada masa awal gerakan mengisi kemerdekaan sampai masa pembangunan sekarang ini, peran pesantren dan ulama' terus meningkat, terutama dalam rangka kerjasama ulama' dan umara' untuk mensukseskan pembangunan bangsa dalam segala bidang sesuai dengan posisi masing-masing. ${ }^{1}$

Pondok Pesantren pada umumnya memiliki beberapa elemen dasar yang merupakan satu kesatuan yang tak terpisahkan dan berada dalam satu komplek. Hal itu menjadi ciri umum bagi Pondok Pesantren. Elemen-elemen tersebut adalah: (1) Pondok, yaitu asrama tempat santri tinggal bersama dan belajar di bawah pimpinan kiai; (2) Masjid, yaitu tempat untuk mendidik dan melatih para santri; (3) Pengajian kitab, yaitu model pengajian yang dilakukan dengan beberapa metode, seperti sorogan, wetonan, bandangan, dan musyawarah atau diskusi; (4) Santri, yaitu siswa yang mencari ilmu di Pondok Pesantren. ${ }^{2}$

Eksistensi Pondok Pesantren dalam menyikapi perkembangan zaman, tentunya tidak terlepas dari komitmen untuk tetap menyuguhkan pola pendidikan yang mampu melahirkan sumber daya manusia (SDM) yang handal, kekuatan otak (berpikir), hati (keimanan), dan tangan (keterampilan). Dalam proses pembelajaran, dahulu pesantren hanya mengedepankan metode pembelajaran bandongan, sorogan dan wetonan. Namun perkembangan pesantren saat ini juga memakai metode diskusi dengan memberikan porsi lebih besar kepada para santri untuk menyampaikan gagasan dalam menginterpretasikan sebuah kitab kajian. Begitu juga dalam mengklasifikasi santri, pesantren modern mengintroduksi sistem kelas yang didasarkan pada pengetahuan yang dimiliki, bukan pada jumlah dan jenis kitab yang telah dikaji.

Pondok modern juga menerapkan pembelajaran bahasa asing (khususnya Arab dan Inggris) sebagai bahasa pengantar yang memungkinkan santri mampu berkomunikasi dengan komunitas intelektual di dunia luar. ${ }^{3}$ Perubahan model dari tradisional menjadi modern memiliki sisi plus dan minus. Sisi plus dari sistem pertama (tradisionalisme) adalah, pada umumnya para santri kuat dalam telaah kitabkitab warisan ulama' klasik. Mereka menguasai teori bahasa arab secara baik, namun kurang menekankan aspek praktis dari pemanfaatan bahasa sebagai alat komunikasi verbal. Sebaliknya, sistem yang kedua (modern) pada umumnya kurang dalam penguasaan kitab-kitab warisan ulama' klasik, namun mereka telah membiasakan bahasa Arab dan Inggris sebagai bahasa pengantar keseharian sehingga santrinya lebih mudah dan cepat dalam mengakses serta berkomunikasi dengan para intelektual di dunia luar.

Namun dari pengalaman perjalanan pesantren, baik yang mengarah pada model tradisional maupun modern, memiliki visi yang sama, yakni mencetak

\footnotetext{
${ }^{1}$ Jamali. Kaum Santri dan Tantangan Kontemporer. (Bandung : Pustaka Hidayah, 1999). 129

2 Khuslan Haludhi, Abdurrohim Sa'id. Integrasi Budi Pekerti Dalam Pendidikan Agama Islam 3. (Malang: PT Tiga Serangkai Pustaka Mandiri, 2008). 106

3 Abdul Munawwar. Belajar Dari Keajegan Proses Pembelajaran Di Pesantren. Seri XI Lectur (Cirbbon; STAIN Cirebon, 2001). 100
} 
generasi yang mendahulukan akhlaq karimah dalam segala tindakan serta menjaga terhadap aturan-aturan syari'at, serta bersikap tawadhu' dalam segala tindakan.

Kelebihan pesantren lainnya adalah terletak pada kemampuannya menciptakan sebuah sikap hidup universal yang merata yang diikuti oleh semua santri, sehingga lebih mandiri dan tidak bergantung pada siapa dan lembaga masyarakat apapun. Perkembangan dan kelebihan pesantren erat kaitannya dengan sistem manajemen yang dikembangkan. Manajemen merupakan suatu konsep yang mengkaji keterkaitan dimensi perilaku, komponen sistem dalam kaitannya dengan perubahan dan pengembangan organisasi. Tuntutan perubahan dan pengembangan yang muncul sebagai akibat tuntutan lingkungan internal dan eksternal, membawa implikasi terhadap perubahan perilaku kelompok dan wadahnya. ${ }^{4}$

Dengan demikian jika terjadi kasus dekadensi moral dikalangan santri maupun guru dapat lebih cepat dicegah penyebarannya. Barangkali inilah nilai posistif dari sistem pendidikan pesantren yang hingga kini masih diidealkan oleh masyarakat muslim di Indonesia. Akan tetapi, menghadapi tantangan dunia global dengan perkembangan teknologi informasi yang begitu dahsyat, pesantren harus segera berbenah diri dan mengambil langkah antisipatif. Pesantren juga dituntut untuk lebih mandiri dan tanggap terhadap tuntutan masyarakat modern yang terus menerus mendambakan kualitas dalam segala hal. ${ }^{5}$ Jika tidak demikian, pesantren tetap akan terkurung dalam orbitnya sendiri, sehingga tidak mampu mengantisipasi perubahan sosial.

Dari sini, hal yang paling urgent yang harus dibenahi oleh pesantren sebagai langkah antisipatif yaitu pembenahan pola manajemen. Sistem pendidikan pesantren biasanya dilakukan secara alami dengan pola manajerial yang tetap (sama) dalam tiap tahunnya. Perubahan-perubahan mendasar dalam pengelolaan pesantren agaknya belum terlihat. Penerimaan santri baru misalnya, masih dilakukan secara terbuka untuk semua individu yang mempunyai latar belakang dan kemampuan beragam tanpa mengadakan usaha pretes terlebih dahulu. Usaha kategorisasi dan klasifikasi santri secara kualitatif jarang sekali dilakukan. ${ }^{6}$

Pengorganisasian pesantren mulai penyiapan fasilitas dan sumber daya manusia, mengatur berbagai komponen secara cermat sampai kepada pelatihan guru dan staf secara teratur, tampaknya, jarang sekali ditemukan pada pesantren, hanya hal-hal lumrah yang dapat ditemukan dalam kehidupan Pesantren. Dalam struktur dan cara pengelolaan, hingga asset pesantren, dikuasai secara turun temurun. Ketakutan terhadap kehilangan aset pesantren ini, menyebabkan diserahkannya pengorganisasian pesantren kepada ahli waris. Efeknya tidak jarang pula para ahli waris memperebutkan pesantren itu agar dia dapat mempunyai andil disana. ${ }^{7}$

Pola-pola manajemen pesantren seperti tersebut diatas sudah seyogyanya mulai dirubah ke arah manajemen yang memadukan aslahah (tradisionalitas) dengan hadatsah (kemodernan). Apabila manajemen yang dipakai hanya berorientasi pada

\footnotetext{
${ }^{4}$ Nanang Fattah. Landasan Manajemen Pendidikan. (Bandung: Remaja Rosda Karya, 2001) 39

5 Tilaar, H.A.R. Beberapa Agenda Reformasi Pendidikan Nasional Dalam Perspektif Abad 21. (Jakarta: Indonesia Tera, 1999). 135

6 Suwendi. Rekontruksi Sistem Pendidikan Pesantren : Beberapa Catatan. (Bandung: Pustaka Hidayah. 1999. 209)

7 Zainal Abidin Anwar. Problem Managerial Pesantren Dalam Peradaban dalam Modern. (Yogyakarta: Pustaka Pelajar, 1908). 201
} 
salah satunya maka akan mengakibatkan split personality (kepribadian yang terpecah) yang tidak mampu memberikan solusi holistik dan integral dalam merespons dinamika zaman.

Kemampuan pesantren untuk tetap bertahan dan bahkan eksistensi pendidikannya diakui sebagai bagian dari sistem pendidikan nasional tidak terlepas dari sistem manajemen pendidikan yang dikembangkan selama ini. Suatu sistem pendidikan (termasuk pondok pesantren) akan menentukan apakah lembaga pendidikan yang bersangkutan akan diminati atau tidak oleh khalayak. Suatu sistem pendidikan dikatakan mampu melayani tantangan zamannya apabila ia mampu merespons kebutuhan anak didik dan mengembangkan kemampuannya sesuai dengan kecenderungannya, merespons kemajuan ilmu dan teknologi, serta kebutuhan pembangunan nasional.

Selain itu pesantren tidak lagi hanya mengelola pendidikan diniyah yang dilakukan dengan seadanya, melainkan mengelola beberapa lembaga pendidikan yang variatif mulai tingkat dasar sampai perguruan tinggi. Pesantren juga mengelola badan usaha seperti persawahan dan koperasi Pondok Pesantren sebagai penyokong finansial, seperti di pesantren Nahdlatun Nasyiin dan Kadur. Semua itu tidak akan berjalan tanpa didukung oleh sumber daya manusia yang cukup banyak. Untuk itulah diperlukan manajemen yang rapi dan transparan. Hal ini sesuai dengan definisi manajemen yang diungkapkan oleh Dale dan Arsyad yaitu : Management is process of working with and trough others to achieve organitational objective in changing environment. ${ }^{8}$

Berdasarkan pada keterangan tersebut diatas, aplikasi konsep manajemen pesantren dalam dunia pesantren dalam rangka mempertahankan eksistensi dan kualitasnya ditengah-tengah maraknya penawaran model pendidikan di Indonesia, merupakan hal yang sangat menarik untuk dikaji dan diteliti lebih lanjut. Diantara pesantren yang telah melakukan perubahan manjemen menuju ke arah pembenahan pola-pola manajemen yang lebih baik adalah Pesantren Nahdlatun Nasyiin Kadur Pamekasan, dengan bukti bahwa pesantren tersebut masih tetap menjadi alternatif utama bagi para orang tua untuk menyekolahkan putra-putri mereka.

Hal tersebut disebabkan oleh adanya jaminan dari aspek moralitas, karena seluruh siswa harus mengikuti setiap kegiatan pondok baik yang menetap di pesantren maupun yang hanya mengikuti sekolah formal di pondok. Selain itu pesantren juga telah menyediakan unit pendidikan yang sangat variatif, mulai dari pendidikan anak usia dini sampai dengan sekolah menengah kejuruan (SMK), dengan kualitas yang hampir sama dengan lembaga pendidikan lain diluar pesantren. Penelitian ini berupaya untuk menemukan dan menggali lebih jauh pola-pola manajemen yang diterapkan oleh Pondok Pesantren Nahdlatun Nasyiin Kadur Pamekasan.

\section{Metode Penelitian}

\footnotetext{
8 Ernest Dale. Management: Theory and practice. (Tokyo : McGraw Hill Kogakusha, 1973). 4 dan Azhar Arsyad. Pokok Pokok Manajemen. (Yogyakarta : Pustaka Pelajar, 2002). 2
} 
Penelitian ini menggunakan metode kualitatif dengan pendekatan fenomenologis. Teknik pengumpulan data metode ini menggunakan observasi, wawancara dan dokumentasi.

Teknik analisis data pada penelitian ini menggunakan teknik reduksi data, display data, conclusion data, dan trianggulasi.

\section{Hasil Penelitian dan Pembahasan}

Secara umum, bila memperhatikan seluk beluk keberadaan Pondok Pesantren Nahdlatun Nasyiin, maka dapat ditemukan beberapa keunggulan dan keunikan di dalamnya, antara lain: (1) pengelolaan Pondok lebih mengedepankan aspek-aspek kekeluargaan, di mana tenaga pendidik dan kependidikannya berasal dari kalangan internal keluarga, dan warga masyarakat sekitar pondok, serta memprioritaskan para alumni yang memiliki kompetensi; (2) menyelenggarakan pembelajaran yang lebih mendalam mengenai ilmu gramatikal bahasa Arab (ilmu nahwu) dan bahkan menjadikannya sebagai ciri khas Pondok Pesantren Nahdlatun Nasyiin; (3) aspek kurikulum lebih menekankan pemberian materi agama, terutama ilmu nahwu; (4) dari aspek sosial masyarakat, Pondok Pesantren Nahdlatun Nasyiin tumbuh dan berkembang dalam Masyarakat yang membudayakan tradisi gotong royong dalam setiap kegiatan, sehingga banyak sekali pembangunan-pembangun sekolah dan pesantren yang berasal dari swadaya masyarakat (5) para santri diberikan keterampilan/kerajinan membuat makanan ringan yang dijual kembali ke para santri dan siswa, sehingga menjadikan Pondok Pesantren Nahdlatun Nasyiin semakin berbeda dengan pondok-pondok yang lain pada umumnya; Selain keunikan dan keunggulan di atas, kekhasan pola penerapan manajemen di Pondok Pesantren Nahdlatun Nasyiin sangat menarik untuk dikaji lebih mendalam lagi.

Perlunya penerapan manajemen dengan pola yang tepat dan efektif didorong oleh suatu kenyataan bahwa perkembangan dunia pendidikan dewasa ini semakin kompetitif. Selain itu tuntutan pelayanan pendidikan yang sesuai dengan standar pelayanan minimal pendidikan mengharuskan lembaga pendidikan seperti pondok pesantren harus berbenah. Dengan demikian, manajemen yang handal merupakan sesuatu yang tidak boleh tidak ada dalam pengelolaan pondok pesantren. Penerapan aspek-aspek manajemen pendidikan di pondok pesantren ini tentunya mencakup semua aspek baik kurikulum, pendidik dan tenaga kependidikan, peserta didik, sarana dan prasarana, pembiayaan dan hubungan masyarakat.

Pondok Pesantren Nahdlatun Nasyiin Kadur telah berupaya melaksanakan manajemen Pondok Pesantren dengan baik. Hal ini bisa di katakan peneliti dari beberapa pendapat pengelola pesantren tentang keterbukaannya terhadap perubahan zaman serta pentingnya peningkatan mutu pesantren dari segala aspek. Mutu layanan pendidikan pesantren sesuai dengan visi dan misi Pondok Pesantren Nahdlatun Nasyiin Kadur yakni mencetak generasi qur'ani yang berakhlakul karimah dan menguasai ilmu pengetahuan serta mendidik generasi yang unggul dalam bidang ilmu pengetahuan dan teknologi dengan bersandarkan pada iman dan taqwa kepada Allah SWT. itu merupakan prinsip dasar penyelenggaraan pesantren Nahdlatun Nasyiin yang terus dikembangkan sesuai dengan tuntutan perubahan zaman.

Untuk menjaga prinsip di atas Pondok Pesantren Nahdlatun Nasyiin Kadur menerapkan pola manajemen yang difokuskan pada perbaikan setiap aspek 
pesantren, khususnya sumberdaya manusia dan sumber daya pendukung seperti adanya pelatihan dan pengembangan guru dan karyawan. Berbagai upaya juga dilakukan pengelola Pondok Pesantren Nahdlatun Nasyiin untuk tetap menjaga kualitas pelaksanan pendidikannya. Secara kognitif, standar mutu santri yang digunakan Pondok Pesantren Nahdlatun Nasyiin berupa pencapaian nilai baik dalam setiap mata pelajaran. Secara afektif, standar kompetensi yang harus dicapai adalah memiliki nilai-nilai etika, estetika, demokrasi, toleransi, dan humaniora dengan dilandasi keimanan dan ketaqwaan kepada Allah SWT serta mampu bertingkah laku secara syar'i sesuai dengan tuntunan ajaran Islam sehingga akan mencapai muslim shalih kamil (utuh) sosial. Secara psikomotorik, standar kompetensi santri yaitu memiliki ketrampilan berkomunikasi, kecakapan hidup dan mampu beradaptasi dengan perkembangan lingkungan sosial budaya dan lingkungan alam baik lokal maupun regional.

Program perbaikan mutu ustadz antara lain pengadaan program workshop dewan asatidz, musyawarah bulanan antara pengasuh, kepala sekolah dan guru dan seminar berkala. Perbaikan mutu santri antara lain adanya beberapa program seperti tes masuk madrasah, praktek komputer, pramuka, kelompok shalawat, pemberian penghargaan kepada santri berprestasi, muhadharah (latihan pidato 4 bahasa: bahasa Arab, Bahasa Inggris, bahasa Indonesia, bahasa Madura), dzibaiyyah (bershalawat kepada Nabi Muhammad SA W dengan menggunakan lagu atau nada), membaca tahlil, ratibul haddad, sorogan kitab, pendalaman ilmu nahwu (program iktisyaf), kajian ilmiah (diskusi), kegiatan hifdhul qur'an, dan pelaksanaan pondok Ramadhan. Kegiatan ini dilakukan baik secara kelompok ataupun individual.

\section{Penutup}

Berdasarkan hasil penelitian diatas dapat disimpulkan pertama Pondok Pesantren Nahdlatun Nasyiin menggabungkan antara kurikulum Kementerian Agama atau Departemen Pendidikan Nasional dengan kurikulum lokal pondok. Untuk mengikuti konsep berpikir pola manajemen pesantren masa depan, menurut pandangan pengelola pesantren Nahdlatun Nasyiin Kadur, maka pola manajemen Pesantren seyogyanya memandang bahwa proses pendidikan adalah suatu peningkatan terus menerus untuk menghasilkan lulusan (ouput) yang berkualitas, pengembangan kurikulum berbasis kompetensi global, proses pembelajaran yang interaktif, sampai kepada ikut bertanggungjawab untuk memuaskan pengguna lulusan itu. Seterusnya berdasarkan informasi sebagai umpan balik yang dikumpulkan dari pengguna lulusan itu, dapat dikembangkan ide-ide kreatif untuk mendesain ulang kurikulum berbasis kompetensi itu atau, memperbaiki proses pendidikan pesantren yang ada saat ini.

Kedua Pondok Pesantren Nahdlatun Nasyiin juga menggabungkan dimensi khazanah lama (al-qadim al-shalih) dengan tradisi luar yang progresif al-jadid al-aslah) dalam pengelolaan pondok sebagai upaya menjaga nilai-nilai baik yang sudah lama menjadi pondasi pesantren serta mampu mengikuti kemajuan ilmu pengetahuan dan teknologi dengan melakukan pemantapan internal dan melakukan penyesuaian visi dan misi pendidikan ke arah perubahan global. Pengembangan sumber daya manusia (dewan asâtidz) dan sumber daya alat atau media yang memadai untuk pencapaian tujuan pendidikan dan pengajaran yang berorientasi pada penguasaan iptek telah dan sedang dilakukan. Dalam kaitannya dengan peningkatan mutu pendidikan di Pondok Pesantren Nahdlatun Nasyiin tampak bahwa program pengelolaan 
pendidikan dan pengajaran dilakukan dalam berbagai aspek yang berkaitan langsung dan tidak langsung terhadap peningkatan mutu proses pendidikan dan terutama peningkatan hasil pendidikan itu sendiri. Terlihat jelas bahwa pengelolaan pendidikan formal selalu berorientasi pada mutu. Pimpinan pondok bersama bersama komponen-komponen yang ada di dalamnya, baik kepala madrasah, kepala sekolah, guru (asâtidz), dan organisasi santri terus melakukan upaya pemantapan internal seperti; peningkatan kualitas dan kuantitas guru, pengadaan fasilitas dan multimedia pembelajaran, optimaliasi kegiatan-kegiatan siswa yang berbasis keterampilan dan kreativitas.

Ketiga untuk dapat memainkan peran edukatifnya dalam penyediaan sumberdaya manusia yang berkualitas Pondok Pesantren Nahdlatun Nasyiin terus meningkatkan mutu sekaligus memperbarui model pendidikannya. Dalam menentukan segala kebijakan terkait peningkatan mutu pesantren, pengelola pesantren selalu melibatkan masyarakat dan wali santri dalam memberikan masukan serta menciptakan hubungan timbal balik yang relatif baik.

\section{Daftar Pustaka}

Jamali. Kaum Santri dan Tantangan Kontemporer. (Bandung : Pustaka Hidayah, 1999).

Haludhi, Khuslan dan Sa'id, Abdurrohim. Integrasi Budi Pekerti Dalam Pendidikan Agama Islam (Malang: PT Tiga Serangkai Pustaka Mandiri, 2008).

Munawwar, Abdul. Belajar Dari Keajegan Proses Pembelajaran Di Pesantren. Seri XI Lectur (Cirbon: STAIN Cirebon, 2001).

Nanang Fattah.. Landasan Manajemen Pendidikan. (Bandung: Remaja Rosda Karya, 2001)

Tilaar, H.A.R. Beberapa \Agenda Reformasi Pendidikan Nasional Dalam Perspektif Abad 21. (Jakarta: Indonesia Tera, 1999).

Suwendi. Rekontruksi Sistem Pendidikan Pesantren : Beberapa Catatan. (Bandung: Pustaka Hidayah. 1999).

Abidin Anwar, Zainal. Problem Managerial Pesantren Dalam Peradaban dalam Modernn. (Yogyakarta: Pustaka Pelajar, 1908).

Mastuhu.. Dinamika Sistem Pendidikan Pesantren. (Jakarta: INIS, 1994).

Dale, Ernest. Management: Theory and practice. (Tokyo : McGraw Hill Kogakusha, 1973)

Azhar Arsyad . Pokok Pokok Manajemen. (Yogyakarta : Pustaka Pelajar, 2002).

Syarif, Zainuddin. Dinamisasi Manajemen Pesantren Dari Tradisional Hingga Modern. (Yogyakarta : Sunan Kalijaga Press, 2007)

Warta Singkat. Pondok Pesantren Al-Amien Prenduan. (Prenduan: tp, 2009). 